\title{
High-selenium wheat: biofortification for better health
}

\author{
Graham Lyons*, James Stangoulis and Robin Graham \\ School of Agriculture and Wine, University of Adelaide, Waite Campus, PMB1, Glen Osmond, 5064, \\ South Australia, Australia
}

\begin{abstract}
The metalloid Se is ubiquitous in soils, but exists mainly in insoluble forms in high-Fe, low-pH and certain leached soils, and hence is often of limited availability to plants. Consequently, it is often supplied by plants to animals and human consumers at levels too low for optimum health. Se deficiency and suboptimality are manifested in populations as increased rates of thyroid dysfunction, cancer, severe viral diseases, cardiovascular disease and various inflammatory conditions. Se deficiency probably affects at least a billion individuals. Optimal cancer protection appears to require a supra-nutritional $\mathrm{Se}$ intake, and involves several mechanisms, which include promotion of apoptosis and inhibition of neo-angiogenesis. Evidence suggests that in some regions $\mathrm{Se}$ is declining in the food chain, and new strategies to increase its intake are required. These could include education to increase consumption of higher-Se foods, individual supplementation, food fortification, supplementation of livestock, Se fertilisation of crops and plant breeding for enhanced Se accumulation. Se levels in Australian residents and wheat appear to be above the global estimated mean. Wheat is estimated to supply nearly half the Se utilised by most Australians. Increasing the Se content of wheat represents a food systems approach that would increase population intake, with consequent probable improvement in public health and large health cost savings. The strategies that show most promise to achieve this are biofortification by Se fertilisation and breeding wheat varieties that are more efficient at increasing grain Se density. Research is needed in Australia to determine the most cost-effective fertilisation methods, and to determine the extent of genetic variability for grain Se accumulation. Before recommending large-scale fortification of the food supply with Se, it will be necessary to await the results of current intervention studies with Se on cancer, HIV and AIDS, and asthma.
\end{abstract}

Selenium: Biofortification: Wheat: Disease prevention

\section{Introduction}

Ever since Se was recognised as an essential nutrient (Schwarz \& Foltz, 1957), a voluminous literature has accumulated that describes the profound effect of this element on human health. The findings of recent human intervention trials (Clark et al. 1996; Yu et al. 1997) have stimulated interest in a cancer-preventive role for Se. In addition to its cancer preventive capacity, Se has an anti-viral effect (Beck et al. 1995; Baum et al. 1997; Yu et al. 1997, 1999). Given the high global incidences of HIV, hepatitis B and C, and other RNA viruses, including measles and influenza, the public-health implications of Se deficiency (estimated by Combs (2001) to affect more than a billion individuals) and suboptimality are enormous.

Several comprehensive reviews have examined Se and human health, including those of Reilly (1996), Rayman
(2000, 2002) and Combs (2001). Combs discusses Se in man within a food systems context and makes the distinction between Se's normal metabolic roles and its anti-carcinogenic activity at supra-nutritional levels.

It is important to note that the biological actions of $\mathrm{Se}$ are not properties of the element per se, but rather are properties of its various chemical forms. Inorganic Se forms (selenate, selenite) undergo reductive metabolism, yielding hydrogen selenide, which is incorporated into selenoproteins. Successive methylation of hydrogen selenide detoxifies excess Se. Selenomethionine can be incorporated non-specifically into proteins in place of methionine, and selenocysteine is catabolised to hydrogen selenide by a $\beta$-lyase (Combs, 2001).

The present review summarises briefly the roles of Se in soils, plants and animals. The importance of Se in human health is discussed, followed by Se intake by human con-

\footnotetext{
Abbreviations: CIMMYT, Centro Internacional de Mejoramiento de Maiz y Trigo (International Maize and Wheat Improvement Centre); NPC, Nutritional Prevention of Cancer.

* Corresponding author: Graham Lyons, fax +61 88303 7109, email graham.lyons@ adelaide.edu.au
} 
sumers, with a focus on Australia. Strategies to increase Se intake are presented. The review then examines wheat as an important source of bioavailable Se, and discusses Se fertilisation and plant breeding, two strategies to increase $\mathrm{Se}$ density in wheat grain.

\section{Background}

Soil Se is uneven in distribution and availability: concentrations range from less than $0 \cdot 1$ to more than $100 \mathrm{mg} / \mathrm{kg}$; however, most soils contain between 1.0 and $1.5 \mathrm{mg} / \mathrm{kg}$ (Berrow \& Ure, 1989). In general, total soil Se of 0.1-0.6 $\mathrm{mg} / \mathrm{kg}$ is considered deficient. Soils in New Zealand, Denmark, Finland (pre-1984, before Se was added to fertilisers), central Siberia, and a belt from north-east to southcentral China are notably Se-deficient and hence have suboptimal levels in their food systems (Gupta \& Winter, 1975; Lag \& Steinnes, 1978; Combs, 2001). Large areas of Africa, including much of Zaire, are also likely to be Sedeficient, but further mapping is required. On the other hand, parts of the Great Plains of the USA and Canada, Enshi County in China, and parts of Ireland, Colombia and Venezuela are seleniferous (Combs, 2001).

In acidic, poorly aerated soils, Se is relatively unavailable to plants and occurs mainly as insoluble selenides and elemental Se. In lateritic soils, which have a high Fe content, Se binds strongly to $\mathrm{Fe}$ to form poorly soluble ferric hydroxide-selenite complexes (Cary \& Allaway, 1969). In wetter regions, selenate can be leached from the soil, resulting in Se-deficient areas, for example, New Zealand and Tasmania (Reilly, 1996). The availability of soil Se to crops can be affected by irrigation, aeration, liming and Se fertilisation (Gissel-Nielsen, 1998).

Australia has both high- and low-Se soils and large areas that have not been mapped for the element. Seleniferous soils occur in central Queensland and parts of Cape York Peninsula. Se deficiency in Australia usually occurs on acidic soils with more than $500 \mathrm{~mm}$ rain annually. Areas include the Central and Southern Tablelands and Slopes and the Northern Tablelands of New South Wales, the south-eastern coast of Queensland, south-west Western Australia; coastal and central regions of Victoria, much of Tasmania, and South Australia's Mount Lofty Ranges and Kangaroo Island (see Fig. 1) (Reuter, 1975; Reilly, 1996).

The Se contents of plants vary according to available soil Se and plant species. For example, wheat grown in Shaanxi Province, China may have $0.003 \mathrm{mg} \mathrm{Se} / \mathrm{kg}$ in the grain, compared with $2.0 \mathrm{mg} / \mathrm{kg}$ for wheat from the North or South Dakota wheatlands (Combs, 2001). Wheat from highly seleniferous areas of South Dakota may contain more than $50 \mathrm{mg} \mathrm{Se} / \mathrm{kg}$ (G Combs, personal communication), while Astragalus on the same soils may accumulate up to $15000 \mathrm{mg} / \mathrm{kg}$ dry weight (Beath et al. 1937).

Although lower plants such as algae require $\mathrm{Se}$ for growth (Lindstrom, 1983), it is not considered to be an essential nutrient for higher plants (Terry et al. 2000), although previous studies to ascertain essentiality failed to account for volatile Se compounds (Broyer et al. 1966).

In higher plants, selenate is absorbed by roots via the

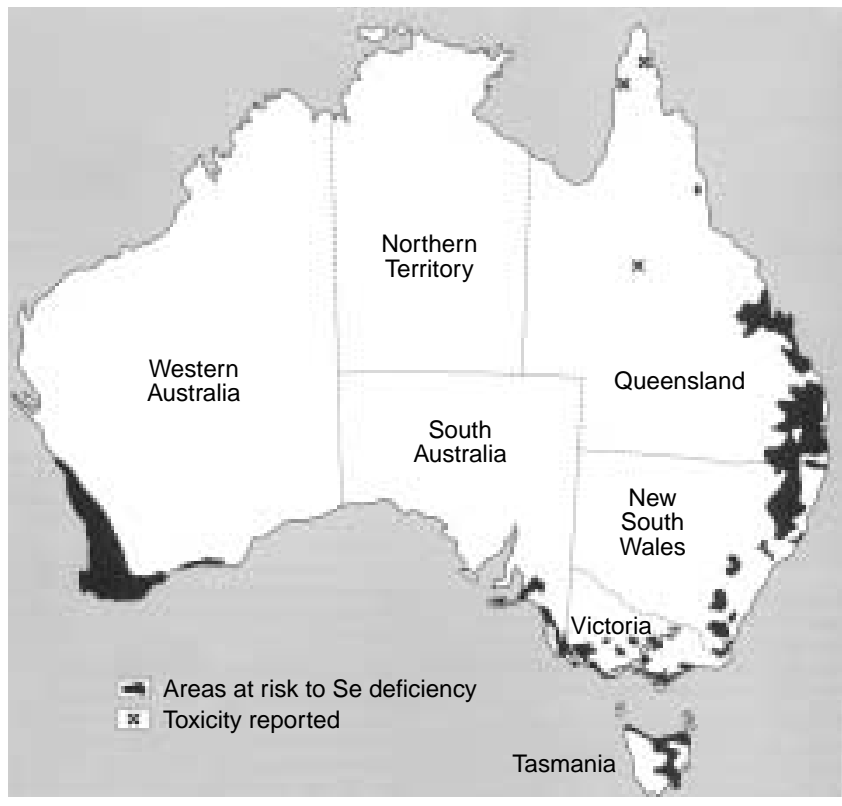

Fig. 1. Selenium in Australian soils (from Judson \& Reuter, 1999).

sulfate transporter, a high-affinity permease. High soil sulfate level decreases selenate influx (Cary \& Gissel-Nielsen, 1973). Se is transported via the xylem to chloroplasts in leaves where it is reduced and the Se converted to organic forms, some of which are volatile. Selenate is transported more easily from root to shoot than is selenite or organic Se (Terry et al. 2000).

Because Se is an essential nutrient, animals respond positively to it where their diet contains less than $0.1 \mathrm{mg} \mathrm{Se} / \mathrm{kg}$ DM (Oldfield, 1993). Conditions that are related to Se deficiency, some of which occur on a wide scale in certain countries, include white muscle disease, exudative diathesis, pancreatic degeneration, liver necrosis, mulberry heart disease and ill-thrift. Se deficiency is usually not the only cause of these diseases (Reilly, 1996).

\section{Selenium: essential for human health}

\section{Selenium-deficiency diseases}

In parts of China and eastern Siberia two overt Se-deficiency diseases occur; Keshan disease and Kaschin-Beck disease. Keshan disease occurs mainly in children and women of childbearing age and involves impairment of cardiac function, cardiac enlargement and arrhythmia (Reilly, 1996). The disease's aetiology is likely to be complex, involving Se and vitamin $\mathrm{E}$ deficiencies, and the presence of the Coxsackie B virus (Yang et al. 1994; Levander \& Beck, 1999; Liu et al. 2002).

Kaschin-Beck disease is an osteoarthropy, which manifests as enlarged joints, shortened fingers and toes, and in severe cases dwarfism. Se and vitamin E deficiency (Reilly, 1996) and I deficiency (Neve, 1999) are likely to be predisposing factors, whereas fulvic acids in drinking water (Peng et al. 1999) or mycotoxins in food (Xiong et al. 1998) are probable causes. 


\section{Antioxidant, anti-inflammatory, thyroid and immunity roles}

Selenocysteine, the twenty-first amino acid, is present in selenoproteins, which have important enzyme functions in man. Glutathione peroxidase (of which at least five forms exist) has an antioxidant role in reducing damaging $\mathrm{H}_{2} \mathrm{O}_{2}$ and lipid or phospholipid hydroperoxides produced in eicosanoid synthesis by the lipoxygenase and cyclo-oxygenase pathways (Spallholz et al. 1990). This function reduces damage to lipids, lipoproteins and DNA, and hence reduces risk of cardiovascular disease and cancer (Diplock, 1994; Neve, 1996). Moreover, selenite inhibits tumournecrosis factor- $\alpha$-induced expression of adhesion molecules that promote inflammation (Zhang et al. 2002).

There is a growing body of evidence to suggest that Se (especially in the sodium selenite form) can alleviate conditions associated with high levels of oxidative stress or inflammation. These include asthma (Shaheen et al. 1999; Jahnova et al. 2002), diabetes (Kowluru et al. 2001), arthritis (Peretz et al. 2001), muscular dystrophy (Kurihara et al. 2000), cystic fibrosis (Kauf et al. 1994), acute pancreatitis (De las Heras Castano et al. 2000), osteoarthritis (Kurz et al. 2002), systemic inflammatory response syndrome (Angstwurm et al. 1999) and kwashiorkor (Ashour et al. 1999). In addition, Schrauzer (1998) discussed the application of selenite therapy to viral haemorrhagic fever, acute septicaemia and lymphoedema. Another group of selenoenzymes, the thioredoxin reductases, are involved in the reduction of nucleotides in DNA synthesis, the regeneration of antioxidant systems, and the maintenance of intracellular redox state (Allan et al. 1999).

The thyroid gland has the highest Se concentration of any human organ (Kohrle, 1999), and Se is involved in thyroid metabolism through the iodothyronine deiodinases, which catalyse the production of active thyroid hormone, $\mathrm{T}_{3}$, from thyroxine, $\mathrm{T}_{4}$ (Beckett et al. 1987). The I deficiency diseases goitre and myxoedematous cretinism are more prevalent in central Africa in those regions that are deficient in both I and Se (Vanderpas et al. 1993), and in such areas supplementation with both nutrients is indicated.

Se has a role in many aspects of the immune response to infections. Se deficiency reduces immunocompetence, involving impairment of neutrophil, macrophage and polymorphonuclear leucocyte activity (Dimitrov et al. 1984; Boyne \& Arthur, 1986; Spallholz et al. 1990). Se supplementation of even supposedly Se-replete individuals is immunostimulatory, and involves enhancement of naturalkiller-cell and lymphocyte activity as well as enhancement of proliferation of activated T-cells (KiremidjianSchumacher et al. 1994).

\section{Cancer}

There is 'perhaps no more extensive body of evidence for the cancer preventive potential of a normal dietary component than there is for selenium.' (Combs \& Gray, 1998). From the late 1960s, epidemiological studies have suggested an inverse association between human Se intake and cancer mortality (Combs \& Gray, 1998). An extensive literature documents the numerous in vitro and animal studies that have been conducted during the past 35 years. Most demonstrate that application or intakes of Se at supra-nutritional levels can inhibit tumorigenesis (El-Bayoumy, 1991; Combs \& Gray, 1998; Ip, 1998). Prospective cohort and case-control studies that have involved as many as 34000 subjects have generally shown an association between low Se status and a significantly higher risk of cancer incidence and mortality (Yoshizawa et al. 1998; Yu et al. 1999; Brooks et al. 2001).

Intervention studies using Se as a single chemopreventive agent include the Qidong trials in China, where selenite significantly reduced primary liver cancer (Yu et al. 1997). In the Nutritional Prevention of Cancer (NPC) trial in the USA, $200 \mu \mathrm{g} \mathrm{Se} / \mathrm{d}$ (as yeast) reduced total cancer mortality by $41 \%$, total cancer incidence by $25 \%$ and prostate cancer incidence by $52 \%$ in a cohort of 1300 subjects. The effect on total cancer was limited to male smokers (current or previous) with baseline Se levels below $113 \mu \mathrm{g} / \mathrm{l}$, although non-smoking males below this level are likely to have benefited from Se supplementation in terms of prostate and colon cancer protection (Duffield-Lillico et al. 2002).

The NPC trial was conducted in a region of the USA where Se intakes are estimated to be around $90 \mu \mathrm{g} / \mathrm{d}$, well above the level required for optimal selenoenzyme activity. This suggests additional mechanisms in Se's cancer-preventive role. While some cancer protection, particularly that through antioxidant activity, involves selenoenzymes, the anti-cancer effects of Se are likely to involve the production of specific anti-tumorigenic metabolites, such as methylselenol. Studies have suggested that Se provided in certain forms can neutralise carcinogens, enhance the immune system, alter gene (including p53) expression, inhibit tumour cell metabolism and neo-angiogenesis (blood vessel development around tumours), and promote apoptosis (programmed cell death) (Ip et al. 1991; Harrison et al. 1997; Combs \& Gray, 1998; Jiang et al. 1999; Combs, 2000, 2001; Lu, 2000; Rayman, 2000; Finley \& Davis, 2001; Seo et al. 2002).

According to this two-stage model of cancer prevention, which involves Se intakes that correct nutritional deficiency as well as much higher, supra-nutritional intakes, individuals with nutritionally adequate Se intakes may benefit from Se supplementation (Combs \& Gray, 1998). Se's anti-cancer activities remain under intensive study worldwide.

\section{Viral and mycobacterial diseases}

Se deficiency is associated with increased virulence of a range of viral infections (Taylor, 1997). It is evident that in a Se-deficient host, normally harmless viruses can become virulent. For example, when Se-deficient mice are inoculated with benign Coxsackie B3 virus, the virus mutates into a virulent form that causes myocarditis similar to that seen in Keshan disease (Beck et al. 1995, 1998; Beck, 2001). Furthermore, Se-deficient mice develop severe pneumonitis when infected with a mild strain of influenza virus (Beck, 2001).

Se appears to be of particular importance for individuals with HIV. Se deficiency is a significant predictor of HIVrelated mortality (Baum \& Shor-Posner, 1998; Campa et al. 1999) and viral load (Baeten et al. 2001). A US study found 
Se-deficient HIV patients to be twenty times more likely to die from HIV-related causes than those with adequate levels (Baum et al. 1997). The decline in blood Se levels occurs even in the early stages and is thus unlikely to be due to malnutrition or malabsorption (Look et al. 1997). Moreover, a study of HIV-1-seropositive drug users found low Se level to be a significant risk factor for developing mycobacterial disease, notably tuberculosis (Shor-Posner $e t$ al. 2002).

Se also appears to be protective in individuals infected with hepatitis B or C against progression to cirrhosis and liver cancer (Yu et al. 1997, 1999). Selenoproteins encoded by HIV, hepatitis $\mathrm{C}$ virus and the Ebola virus (which causes acute haemorrhage) have been discovered that consume the host's Se supply, thus reducing the immune response (Taylor \& Nadimpalli, 1999; Zhao et al. 2000).

\section{Other health effects}

Low Se status has long been known to reduce fertility in livestock (Underwood, 1977), and this also appears to be the case for man. Low Se levels have been associated with male infertility (Behne et al. 1997) and spontaneous abortions (Barrington et al. 1996). In a Scottish study, supplementation of subfertile men with $100 \mu \mathrm{g}$ Se/d for 3 months significantly increased sperm motility (Scott \& MacPherson, 1998). Conversely, Hawkes \& Turek (2001) found that a diet containing $300 \mu \mathrm{g} \mathrm{Se} / \mathrm{d}$ caused a reduction in sperm motility in healthy men.

Se appears to be influential in the brain, and Rayman (2000) documented several studies that indicate that low Se levels are associated with cognitive impairment, depression, anxiety and hostility. These conditions can be alleviated in individuals with low baseline Se levels by $\mathrm{Se}$ supplementation. Recent studies suggest that selenoprotein $\mathrm{P}$ (Whanger, 2001), selenoprotein W (Jeong et al. 2002) and the newly discovered selenoprotein M (Korotkov et al. 2002) have important roles in the brain.

$\mathrm{Se}$ forms selenides with all metals, and detoxifies $\mathrm{Hg}$, $\mathrm{Cd}, \mathrm{Pb}, \mathrm{Ag}, \mathrm{Tl}$ and $\mathrm{As}$. This effect can be enhanced by vitamin E (Frost, 1981). In the case of $\mathrm{Cd}$ and $\mathrm{Hg}$, detoxification is achieved through the diversion in their binding from low- to high-molecular-weight proteins (Whanger, 1992).

\section{Human selenium intake}

\section{Selenium intake: low and getting lower}

Se intake in human consumers is determined mainly by the level of available $\mathrm{Se}$ in the soil in which their food is grown, and by dietary composition. Se levels in major food classes usually occur within the following ranges: $0 \cdot 10-0.60 \mathrm{mg} / \mathrm{kg}$ (fish); 0.05-0.60 (cereals); 0.05-0.30 (red meats); 0.002-0.08 (fruit and vegetables) (Combs, 2001). Bioavailability, which varies with the food source of Se, will be discussed on p. 52 .

The absolute range of global daily Se intake by adults is between 7 (in Chinese Keshan disease areas) and $5000 \mu \mathrm{g} / \mathrm{d}$ (in Chinese selenosis areas). Estimates provided by Combs (2001) of Se intake for several countries include England (12-43), Belgium (45), Canada (98-224), USA (60-220),
Croatia (27), New Zealand (19-80), Japan (104-127) and Venezuela (200-350). In Australia few comprehensive studies have been conducted, but estimates of 63 and $96 \mu \mathrm{g} / \mathrm{d}$ have been provided, with a range of 23-204 $\mu \mathrm{g} / \mathrm{d}$ (Fardy et al. 1989; Reilly, 1996). In view of the estimated mean plasma level of Se in Australian adults (see p. 49), a mean intake of around $75 \mu \mathrm{g} / \mathrm{d}$ appears likely for Australians.

The US recommended daily allowance, which is based on the Se levels considered to be necessary to maximise glutathione peroxidase activity, is $55 \mu \mathrm{g} / \mathrm{d}$ for both men and women, while in Australia it is 85 and $70 \mu \mathrm{g} / \mathrm{d}$ for men and women, respectively. The Third National Health and Nutrition Examination Survey in the USA ( $n$ 17 630) indicated that $99 \%$ of the subjects were Se-replete (i.e. above $80 \mu \mathrm{g} \mathrm{Se} / \mathrm{l}$ plasma) and thus supplementation is not recommended (Burk, 2002). However, referring to the study of Neve (2000), Rayman (2000) pointed out that if platelet, rather than plasma, saturation of glutathione peroxidase activity is used as the measure of Se repletion, a higher intake is required, in the range of $80-100 \mu \mathrm{g} / \mathrm{d}$.

It is evident that many individuals do not consume enough Se to support maximum expression of selenoenzymes, let alone the level required for optimum prevention of cancer. Combs (2001) estimated the number of those who are Se-deficient in the world to be in the range of 500-1000 million. In addition, he considered that the vast majority of the world's population have suboptimal Se intakes, and hence are at increased risk of cancer, heart disease, viral diseases, and indeed any conditions that involve increased levels of oxidative stress.

Furthermore, evidence suggests that there is a trend toward a reduction of Se in the global food chain, caused by fossil fuel burning (with consequent $\mathrm{S}$ release), acid rain, soil acidification, the use of high-S fertilisers (Frost, 1987) and more intensive crop production (Gissel-Nielsen, 1998). Rayman (1997, 2000, 2002) and Giovannucci (1998) have observed that blood Se levels have decreased significantly in the UK during the decade 1984-1994, and current average Se intake in the UK may be as low as $34-39 \mu \mathrm{g} / \mathrm{d}$ (Barclay et al. 1995; Ministry of Agriculture, Fisheries and Food, 1997, 1999). These authors attribute this fall in part to the use of low-Se UK and European wheat in place of North American wheat. This highlights the sensitivity of Se intake and body levels to changes in the food supply. Both authors call for action to increase Se intake.

\section{Human blood concentrations of selenium: the global view}

Blood Se levels are determined mainly by dietary intake, although gender, age, smoking and exposure to heavy metals can have an effect (Robberecht \& Deelstra, 1994). Combs (2001) presented a comprehensive list of Se concentrations in plasma, serum or whole blood of healthy adults from sixty-nine countries. A sample of plasma or serum Se concentrations ( $\mu \mathrm{g} / \mathrm{l})$ is as follows: Austria (67); Burundi (15); Canada (132); China, Keshan disease area (21); China, selenosis area (494); Finland pre-1984 (70); Finland post-1984 (92); Hungary (54); Japan (130); New Zealand (59); Norway (119); USA (119); Zaire (27) (Combs, 2001). Note that there are few data available from some of the most populous areas of the world, including 
most of Africa, South America and central and south Asia. The mean value (calculated as the mean of the post-1990 means for a representative sample of forty-five countries) is $78 \mu \mathrm{g} / \mathrm{l}$, with a range of means from 15 (Burundi) to 216 $\mu \mathrm{g} / \mathrm{l}$ (Venezuela). However, this is likely to be optimistic as small studies of Se levels in much of Africa and central, south and South-East Asia indicate levels well below this.

This can be compared with the value of $70 \mu \mathrm{g} / \mathrm{l}$, the WHO's reference level, which is the minimum level for maximisation of plasma or serum glutathione peroxidase activities (Neve, 1995). Rayman (1997) has quoted studies that show that a level of $100 \mu \mathrm{g} / \mathrm{l}$ is required for optimal expression of plasma glutathione peroxidase. The vast majority of the world's population would not reach this level of plasma or serum Se.

\section{Selenium levels in the Australian population}

An estimate of $94 \mu \mathrm{g} / \mathrm{l}$ of plasma or serum Se for Australia can be derived from the means determined from seventeen studies of blood Se levels. The studies (with mean plasma or serum Se levels in $\mu \mathrm{g} / \mathrm{l})$ are: Judson et al. $(1978,1982)$ (124, 114); Pearn \& McCay (1979) (88); McOrist \& Fardy (1989) (98, 86); Brock et al. (1991) (88); Cumming et al. (1992) (81); Lux \& Naidoo (1995) (101); McGlashan et al. (1996) (80); Dhindsa et al. (1998) (92); Daniels et al. (2000) (77, 88); GJ Judson, (unpublished results from 1987 and 1988) (91, 92, 101, 95); G Lyons, GJ Judson, J Stangoulis, L Palmer and R Graham (unpublished results from 2002) (103). If post-1990 data only are used, the mean is $89 \mu \mathrm{g} / \mathrm{l}$. Using either mean, Australia is above the estimated world mean reported Se level of $78 \mu \mathrm{g} / \mathrm{l}$.

In Australia, relatively low blood Se levels have been reported in Adelaide infants. Daniels et al. (2000) found a plasma Se level of around 31 (SD 13) $\mu \mathrm{g} / \mathrm{l}$ in a sample of newborn infants, a level comparable with that of New Zealand. Infant Se levels are typically half those of adults. These levels place the infants at increased risk of a range of conditions that involve oxidative stress and inflammation.

An apparent global decline in Se in the food chain was noted on p. 48. Se levels in South Australians may have fallen from 1977-1987. For instance, the mean wholeblood Se level for a 1977 sample of Adelaide health workers was $155 \mu \mathrm{g} / \mathrm{l}$ (Judson et al. 1978), whilst Kangaroo Island residents in 1979 recorded a mean of $143 \mu \mathrm{g} / \mathrm{l}$ (Judson et al. 1982). However, in later samples of healthy Adelaide adults from 1987-2002, mean whole-blood Se levels were 117, 126, 128, 118 (GJ Judson, unpublished results from 1987 and 1988) and $125 \mu \mathrm{g} / \mathrm{l}$ (G Lyons, GJ Judson, J Stangoulis, L Palmer and R Graham unpublished results from 2002), with Mount Gambier residents recording $121 \mu \mathrm{g} / \mathrm{l}$ in 1987 (GJ Judson, unpublished results from 1987), for a grand mean for the period 1987-2002 of 123 $\mu \mathrm{g} / \mathrm{l}$. The apparent decline in the early 1980 s may be due to changes in dietary composition and/or a decrease in Se concentration in South Australian-grown wheat.

\section{Optimum selenium intake}

In the NPC trial in the USA, the protective effect of Se against cancer occurred in the lowest (relative risk 0.52;
$95 \%$ CI $0.33,0 \cdot 82$ ) and middle (relative risk $0.64 ; 95 \% \mathrm{CI}$ $0.40,0.97$ ) tertiles, which included those individuals with plasma Se levels below $121 \mu \mathrm{g} / \mathrm{l}$ (Rayman \& Clark, 2000). The latest analysis shows that the Se benefit was largely restricted to male smokers with baseline plasma Se levels below $113 \mu \mathrm{g} / \mathrm{l}$. The strongest protective effect was against prostate cancer, with a hazard ratio of 0.48 (95\% CI 0.28 , 0.80) (Duffield-Lillico et al. 2002). None of the subjects had plasma Se levels below $60 \mu \mathrm{g} / \mathrm{l}$ and very few were less than $80 \mu \mathrm{g} / \mathrm{l}$; thus the cohort must be considered Se-adequate by current nutritional standards (Combs, 2000).

Although there is a risk in generalising results of individual epidemiological and intervention studies, this result would suggest, using the levels presented by Combs (2001) on p. 48, that the vast majority of the world's population (including that of Australia, with a probable mean plasma or serum level around $89 \mu \mathrm{g} / \mathrm{l}$, and many populations in Europe (Rayman, 2000)) would be in the responsive range.

The NPC participants lived in a region where dietary Se intake is around $90 \mu \mathrm{g} / \mathrm{d}$ (Clark et al. 1996); thus with the addition of the $200 \mu \mathrm{g}$ supplement, subjects in the treatment group would have received around $270-310 \mu \mathrm{g} / \mathrm{d}$. Combs (2001) suggested that an Se intake of $200-300 \mu \mathrm{g} / \mathrm{d}$ may be required to significantly reduce cancer risk. This compares with an estimated Australian adult intake of 75 $\mu \mathrm{g} / \mathrm{d}$. Of course, as Rayman (2000) noted, Se requirement varies between individuals in the same population. Even Moyad (2002), who expressed doubts about the interpretations of certain Se studies, and considered some estimates of its cancer-protective effect to be optimistic, suggested that an intake of $200 \mu \mathrm{g} \mathrm{Se} / \mathrm{d}$ and around $50 \mathrm{mg}$ vitamin E/d may be beneficial, particularly for current or previous smokers. The results of the NPC trial (Duffield-Lillico et al. 2002) suggested that males may have a higher Se requirement than females. Further studies may find optimum adult Se intakes in the range $125-280 \mu \mathrm{g} / \mathrm{d}$, with means of around 130 (for females) and $250 \mu \mathrm{g} / \mathrm{d}$ (for males). Pregnant females may have a higher Se requirement than non-pregnant females (Dylewski et al. 2002).

Chronic selenosis occurs in Enshi County, China, where coal-contaminated soil contains up to $8 \mathrm{mg} \mathrm{Se} / \mathrm{kg}$, and residents have consumed up to $7 \mathrm{mg} / \mathrm{d}$. Common symptoms include nail thickening and cracking and hair loss, and some individuals exhibit skin lesions (Liu \& Li, 1987; Yang \& Zhou, 1994). The concern that the incorporation of selenomethionine into body proteins could increase Se to toxic levels appears unwarranted because a steady state is established, which prevents the uncontrolled accumulation of Se (Schrauzer, 2000).

Combs (2001) considered it probable that the WHO and European Union estimates of the upper safe limit of Se intake of 400 and $300 \mu \mathrm{g} /$ adult per $\mathrm{d}$, respectively, are too conservative. Under normal conditions, a Se intake of less than $1000 \mu \mathrm{g} / \mathrm{d}$ (or $15 \mu \mathrm{g} / \mathrm{kg}$ body weight) does not cause toxicity (Neve, 1991; Poirier, 1994; Whanger et al. 1996; Taylor, 1997). Those living in parts of China, the USA, Venezuela and Greenland have ingested Se at this level for their entire lives without ill effects (Taylor, 1997).

However, it would be prudent at this stage to limit medium- to long-term Se intake to around the US reference dose, which has been set at $350 \mu \mathrm{g} / \mathrm{d}$ for a $70 \mathrm{~kg}$ human 
adult (Schrauzer, 2000), for several reasons. First, Vinceti et al. (2001) have documented possible adverse effects of levels of supplemented Se around $300 \mu \mathrm{g} / \mathrm{d}$ on thyroid status. Second, a reduction in sperm motility in a group of eleven men supplemented with $300 \mu \mathrm{g} \mathrm{Se} / \mathrm{d}$ for 3 months has been shown by Hawkes \& Turek (2001). Third, there has been a surprising finding from the NPC trial of a non-significant increase in risk (based on small case numbers) of five cancer types (melanoma, lymphoma and leukaemia, breast, bladder and head and neck cancers) in the Se-supplemented group. Biofortification of cereals with $\mathrm{Se}$ at the rates discussed on p. 53 would be very unlikely, though, to place consumers at risk of any adverse health effects from Se.

The food systems of very few countries appear to deliver an optimum level of Se to their populations, and indeed the food systems of most populations do not even provide enough Se to maximise selenoenzyme expression. The impact of this deficiency and suboptimality in global health terms is difficult to quantify, but is likely to be enormous given the high prevalence of various cancers, cardiovascular diseases, viral diseases (including AIDS, hepatitis, measles and influenza), and exposure to environmental pollutants throughout much of the world. It is thus a matter of urgency that many countries begin to address this major public-health issue and develop effective, sustainable ways to increase Se intakes (Combs, 2001).

\section{Strategies to increase human selenium intake}

Given that the populations of most countries would probably benefit from an increased Se intake, how could this be best achieved? Strategies to increase Se intake include increased consumption of higher-Se foods through education, individual supplementation, food fortification, supplementation of livestock, use of Se fertilisers, and plant breeding for enhanced Se accumulation. Each of these shall be discussed briefly.

\section{Increased consumption of higher-selenium foods through education}

Globally, wheat is one of the most important dietary sources of Se. Even in Europe, with its low levels of available soil Se, bread and cereals, being commonly consumed, are important Se sources. In the UK, for example, it is estimated that bread and cereals supply around $22 \%$ of Se, second to meat, poultry and fish (36\%) (Ministry of Agriculture, Fisheries and Food, 1997).

Brazil nuts provide the most concentrated natural food source of Se. A study conducted in the UK found concentrations of 2-53 mg Se/ $\mathrm{kg}$ (Thorn et al. 1976), while an Australian study found even higher levels; $0 \cdot 5-150 \mathrm{mg} / \mathrm{kg}$ (Tinggi \& Reilly, 2000).

\section{Individual supplementation}

In Western countries, many individuals currently consume Se supplements, which are available in both inorganic and organic forms. Sodium selenite, available in tablet or fluid form, is preferable to selenate (Chen et al. 2000; Finley \& Davis, 2001). High-Se yeast includes several organic Se forms, including selenomethionine and selenocysteine (Bird et al. 1997). Another form of individual supplementation is selective consumption of the fortified or 'functional foods' listed later.

Studies suggest that dietary sources of Se, vitamin E and $\beta$-carotene are preferable to supplements (Moyad, 2002). Moreover, a well-known drawback of individual supplementation as a population strategy to improve nutrition is that those who are most in need tend to be the least likely to take supplements.

\section{Food fortification}

This approach has been used successfully with folateenriched breakfast cereals, Fe-enriched milk, iodised salt, carotene- and vitamin E-enriched margarine, as well as selenised salt in Se-deficient regions of China. Seleniferous areas can be considered resources for the production of Seenriched plants; for example, in China an elixir is made from high-Se tea in Enshi County (Combs, 2001). These examples can be included in the functional foods category, along with high-Se broccoli (Finley, 1999), high-Se garlic (Ip \& Lisk, 1994) and the high-Se yeast noted earlier.

\section{Selenium supplementation of livestock}

Supplementation strategies to increase dietary Se intake by livestock (and thus increased levels in meat and milk) include Se fertilisation of pastures, dietary supplements (for example, the now widespread practice of adding selenomethionine to the rations of livestock, including dairy cows during milking), and direct administration (drenches, slowrelease reticulum-rumen 'bullets', injection).

In New Zealand, sodium selenate is supplied as a prill to pastures (Reilly, 1996). In a Western Australian study, slow-release barium selenate applied at $10 \mathrm{~g} / \mathrm{ha}$ prevented subclinical Se deficiency in sheep for 4 years, whereas a single application of sodium selenate at the same rate was effective for only 15 months (Whelan \& Barrow, 1994).

Supplementation of livestock with Se is unlikely to be an efficient strategy to increase Se level in the human population, however. In New Zealand, little increase in the Se content of human foods was observed after the introduction of Se supplementation for farm animals in the 1960s (Thomson \& Robinson, 1980).

\section{Selenium fertilisation of crops}

The use of Se as a soil amendment in fertiliser is practised mainly in Finland (by law from 1984), where it is currently added to N, P and $\mathrm{K}$ fertiliser at a rate of $10 \mathrm{mg} / \mathrm{kg}$ (Eurola \& Hietaniemi, 2000), and New Zealand (at an individual level, and generally on pastures).

The Finnish experiment has demonstrated the safety, effectiveness, ease and cost-efficiency of this approach to raise Se levels in a human population. Dietary Se intakes trebled and plasma Se concentrations nearly doubled within 3 years of the programme's commencement (Aro et al. 1995). However, it is difficult to isolate the effects of a single factor, such as dietary change, from other factors that can be involved in the aetiology of such conditions as can- 
cer and cardiovascular disease. There have been significant decreases in the rates of cardiovascular disease and certain cancers in Finland since 1985, but with no controls for comparison, this cannot be ascribed to Se alone (Varo et al. 1994).

Sodium selenate is the Se form generally used for crop and pasture fertilisation; it is weakly adsorbed on soil colloids and can bring about a rapid increase in plant Se level (Gupta \& Watkinson, 1985). The enhancement of wheat-Se level by fertiliser will be discussed further on p. 52 .

\section{Plant breeding for enhanced selenium accumulation}

Breeding for improved Se uptake and/or retention by plants may be an effective, sustainable strategy. Preliminary studies have found a 15-fold variation in Se-accumulating ability among brassica vegetables (Combs, 2001), and an Se-accumulating soyabean cultivar has been identified (Wei, 1996). Substantial variability exists within cereal crop varieties for $\mathrm{Zn}, \mathrm{Fe}$ and other nutrients (Graham et al. 1999). These findings suggest that it should be possible to breed cultivars with enhanced Se uptake and/or retention, or to use genetic engineering to enhance Se levels (and even specific Se metabolites) in food crops.

In summary, each of these strategies could contribute to an enhanced delivery of Se to human populations through their food systems. As described by Welch \& Graham (1999), a food systems paradigm encompasses an agriculture that aims not only at productivity and sustainability, but also at improved nutrition. In Australia, a programme that combines selection for enhanced grain Se content in wheat, strategic fertilisation of wheat and barley, education to encourage greater consumption of higher-Se foods, increased supplementation of livestock grazing on acid soils in high rainfall areas, and education and targeted supplementation of high-risk individuals, would be likely to significantly improve population health.

\section{Wheat: an important selenium source for human consumers}

Surveys indicate that wheat is the most efficient Se accumulator of the common cereal crops (wheat, rice, maize, barley, oats) and is one of the most important Se sources for human consumers. In a Russian survey, serum Se level was found to be highly correlated $(r 0.79)$ with Se level in wheat flour (Golubkina \& Alfthan, 1999). Bread is the second most important source of Se in the USA (Schubert et al. 1987), and has been found to supply one-third of the daily Se intake of Australian children (Barrett et al. 1989). With the addition of Se supplied through breakfast cereals, cake and biscuits, and in view of its high bioavailability, wheat-Se probably supplies around half the Se utilised by Australians.

\section{Selenium concentrations in wheat grain}

The global view. There is wide variation in wheat-grain Se level between and within countries. Published values range from $0.001 \mathrm{mg} / \mathrm{kg}$ in south-west Western Australia (White et al. 1981) to $30 \mathrm{mg} / \mathrm{kg}$ in highly seleniferous areas of South Dakota (University of California, 1988), but most of the world's wheat falls within the $0.020-0.600 \mathrm{mg} / \mathrm{kg}$ range (Alfthan \& Neve, 1996). Canada and the USA have relatively high levels, usually in the $0 \cdot 2-0.6 \mathrm{mg} / \mathrm{kg}$ range (Reilly, 1996). New Zealand and Eastern Europe generally have low levels, for example, the $0.028 \mathrm{mg} / \mathrm{kg}$ average found by Mihailovic et al. (1996) for Serbia.

Some countries, including China (with a range of 0.01-0.23 mg/kg; Alfthan \& Neve, 1996), Canada and the USA, have highly variable wheat-Se levels, even within states. Se concentrations in wheat grain from twelve locations in Manitoba, Canada in 1986-1988 ranged from $0.06-3.06 \mathrm{mg} / \mathrm{kg}$, and levels varied between years within a location (Boila et al. 1993). A US survey, also in 1986-1988, analysed major brands of white bread in nine different geographical regions. The overall range was $0 \cdot 06-0.74 \mathrm{mg} / \mathrm{kg}$, while a single brand of bread collected from different bakeries in Boston alone had a range of $0.24-0.92 \mathrm{mg} / \mathrm{kg}(\mathrm{CV} 41 \%)$, with a mean of $0.60 \mathrm{mg} / \mathrm{kg}$ (Holden et al. 1991).

Selenium in Australian wheat. Four published surveys of Se concentrations in Australian wheat have been identified. The Queensland study (Noble \& Barry, 1982) found a mean value for wheat-grain-Se of 0.150 (range $0 \cdot 020-0 \cdot 800$ ) $\mathrm{mg} / \mathrm{kg}$ for wheat grown between 1974 and 1978. Similar levels were found for sorghum and soyabean. Site differences accounted for a 40 -fold difference between wheat-Se values, and a 110-fold difference for sorghum.

Very low Se concentrations were found in wheat surveyed in south-west Western Australia in 1975; mean Se concentration in grain was $0.023(\mathrm{SE} 0.006) \mathrm{mg} / \mathrm{kg}$, with a range of $0.001-0.117 \mathrm{mg} / \mathrm{kg}$ (White et al. 1981). The value of 0.001 $\mathrm{mg} / \mathrm{kg}$ is the lowest level reported globally for Se in wheat. The lowest levels were found on soils derived from Archaean granite, which are also associated with a high prevalence of white muscle disease in lambs (Godwin, 1975).

Watkinson (1981) compared Se concentrations in New Zealand-grown wheat with wheat imported from Australia, grown in 1978 and 1979. The Australian wheats were higher in $\mathrm{Se}$ (mean 0.123 (SD 0.026) $\mathrm{mg} / \mathrm{kg}$, range $0.043-0.224 \mathrm{mg} / \mathrm{kg}$ ) than the New Zealand wheats (mean 0.028 , (SD 0.010) $\mathrm{mg} / \mathrm{kg}$, range $0.011-0.086 \mathrm{mg} / \mathrm{kg}$ ).

The South Australian study (Babidge, 1990) used pooled wheat and barley samples from 107 and 100 silos, respectively, across the state in the 1981 season for wheat and the 1981 and 1982 seasons for barley. There were significant differences $(P<0.001)$ between regions; for example, the Upper Eyre Peninsula region had a wheat-Se median value of 0.229 (range $0 \cdot 120-0.316) \mathrm{mg} / \mathrm{kg}$, compared with the South East with $0 \cdot 118$ (range 0.047-0.240) $\mathrm{mg} / \mathrm{kg}$. Wheat and barley showed the same regional trends, but wheat levels were around $30 \%$ higher.

A recent targeted survey of wheat grown in South Australia in the 2000 and 2001 seasons yielded a range of $0.005-0.700 \mathrm{mg} \mathrm{Se} / \mathrm{kg}$, with values typically $0.080-0 \cdot 160$ $\mathrm{mg} / \mathrm{kg}$, and an estimated grand mean of $0.120 \mathrm{mg} / \mathrm{kg}(\mathrm{G}$ Lyons, L Palmer, J Stangoulis and R Graham, unpublished results).

The findings of these studies (means of $0 \cdot 150$ (Queensland), 0.023 (Western Australia), 0.150 (South 
Australia), 0.091 (New South Wales), and South Australia median of $0.170 \mathrm{mg} / \mathrm{kg}$ ), together with the findings of the human blood surveys discussed on p. 48, suggest that Australian wheat-grain Se concentrations are above the global average. They are well above the New Zealand, UK and Eastern European levels, but generally lower than those of Canada and the USA.

\section{High bioavailability of wheat-selenium}

In human nutrition terms, bioavailability can be defined as the amount of a nutrient in a meal that is absorbable and utilisable by the individual eating the meal (Van Campen \& Glahn, 1999). Se is well absorbed (generally 73-93\%) from most sources, with selenomethionine and selenate usually absorbed more efficiently than selenite (Raghib et al. 1986; Stewart et al. 1987; Moser-Veillon et al. 1992; Van Dael et al. 2002).

However, the assessment of bioavailability of food micronutrients in general (House, 1999; Graham et al. 2001) and different forms of dietary Se is not straightforward (Reilly, 1996). Several measures can be used to determine bioavailability and they are subject to a range of variables. If tissue retention is used as a measure, naturally occurring food Se is by far the most available form of the element, although there are significant differences between different types of food.

Se form is important; selenomethionine, the form in which Se mainly occurs in cereals (Olson et al. 1970), beans, mushrooms and yeast (Reilly, 1996), enters the general protein pool and is well retained. However, it must be released from the protein pool and be catabolised to hydrogen selenide before it can support selenoenzyme expression. Selenocysteine, on the other hand, cannot be incorporated directly into proteins, but is catabolised directly to hydrogen selenide. It is thus better utilised for the selenoenzymes but not retained as well as selenomethionine (Deagen et al. 1987; Levander \& Burk, 1990; Combs, 2001).

Se is generally more bioavailable from plant forms than from animal foodstuffs (Combs, 1988; Bugel et al. 2002), and wheat-Se is one of the most bioavailable forms (Jaakkola et al. 1983; Laws et al. 1986; Hakkarainen, 1993). The importance of imported North American wheat as a former Se source for the British population was noted on p. 48. This is reinforced by a Scottish study which found that the Se content of wheat harvested in 1989, which was used for bread making in Scotland, ranged from 0.028 $\mathrm{mg} / \mathrm{kg}$ for home-grown wheat to $0.518 \mathrm{mg} / \mathrm{kg}$ for Canadian wheat, and was significantly correlated $(P<0 \cdot 001)$ with protein content (Barclay \& MacPherson, 1992). Norway's population, despite a modest total Se intake, has the highest serum Se level in Europe at $119 \mu \mathrm{g} / \mathrm{l}$. The probable explanation is that their major Se source is North American wheat. In a Norwegian study, Meltzer et al. (1992) demonstrated the high bioavailability of wheat-Se by feeding trial participants Se-rich bread providing 100, 200 or $300 \mu \mathrm{g} \mathrm{Se}$ daily for 6 weeks. Serum Se increased in a dose-response manner by 20,37 and $53 \mu \mathrm{g} / \mathrm{l}$, respectively, in the three groups $(P<0 \cdot 001)$.

Wheat enriched with Se by foliar application was found to be highly effective in raising plasma Se $53 \%$ increase after 6 weeks) in a Serbian study. Glutathione peroxidase activity in blood increased and oxidative stress parameters decreased (Djujic et al. 2000b). A follow-up study found that $\mathrm{Se}$-enriched wheat increased levels of $\mathrm{Cu}, \mathrm{Fe}$ and $\mathrm{Zn}$ in erythrocytes, compared with individuals consuming low-Se wheat (Djujic et al. 2000a). This is the first time such interactions have been reported, and further studies are warranted in view of the billions in the human population who are $\mathrm{Fe}$ - and/or Zn-deficient.

\section{Strategies to increase selenium in wheat}

\section{Background}

The foregoing evidence suggests that for many countries an increase in Se concentration in wheat would be the most effective and efficient way to increase the Se intake of the human population, with consequent probable improvement in public health, and also to reverse the trend of declining Se levels in food systems.

It is clear that Se fertilisation of wheat is an effective means to increase grain Se concentration (Gupta \& Gupta, 2000; Combs, 2001), and this will be examined later. Education is also important to encourage the consumption of appropriate amounts and proportions of different classes of healthy foods, including whole-grain cereal products.

However, in developing countries those individuals who are most at risk of nutrient deficiencies (frequently women and children) often rely on one staple food, for example wheat, rice, cassava or maize, for most of their energy and nutrient requirements, and lack the money to improve their diet. Hence the high prevalence of Fe, Zn, vitamin A, I and Se deficiencies, and the high incidence and prevalence of infectious diseases in these countries (Graham \& Welch, 1996; Graham et al. 2001). For certain soil types in developing countries, the most sustainable, cost-effective approach may be to breed wheat cultivars that are better at accumulating grain-Se.

\section{Selenium fertilisation}

To overcome the low Se levels in food crops in certain areas, different methods of Se fertilisation have been investigated for more than 30 years. Of particular interest are the experiments of Ylaranta (Finland), Gissel-Nielsen (Denmark) and Gupta (Canada). It is a very inexpensive method to increase Se intake by human consumers; the material cost of applying $10 \mathrm{~g}$ selenate/ha is around US $\$ 1 \cdot 15 /$ ha ( $€ 1 \cdot 15 /$ ha). Its effectiveness is illustrated by the increase in blood Se levels in Finland post-1984. Moreover, Mutanen et al. (1987) found that the bioavailability (calculated as the mean of four criteria) of wheat-Se was higher for Se-fertilised (both soil-applied and foliar) wheat than for American wheat, which was naturally high in Se.

The Finland Se programme was discussed on p. 50. The Se level in all domestic cereal grains in Finland pre-1984 was $0.01 \mathrm{mg} / \mathrm{kg}$ or less; now spring wheats typically contain around $0.25 \mathrm{mg} / \mathrm{kg}$, and for the less-fertilised winter wheat, around $0.05 \mathrm{mg} / \mathrm{kg}$ (Eurola et al. 1990). Current 
application rate is $5-10 \mathrm{~g}$ selenate/ha, and the practice appears to be safe.

The concern that the continuing use of Se-amended fertilisers might eventually lead to accumulation of toxic levels in the environment appears to be unfounded (Vuori et al. 1994; Oldfield, 1999). The residual effect of Se treatments was found to be low to negligible in the following year, even when it had been applied at the high rate of 500 g/ha (Ylaranta, 1983a,b, 1984; Singh, 1991; Shand et al. 1992; Gupta et al. 1993). Furthermore, the bioavailability of residual $\mathrm{Se}$ is lowered by the reducing action of microorganisms in the soil and rumen. A Californian study (Norman et al. 1992) found that long-term Se supplementation of cattle at maximum permitted levels did not result in Se contamination in streams that received runoff from feeding areas. However, a Californian study of a deer forest range treated with seleniferous fertiliser found significant Se accumulation in aquatic biota in streams in the same area (Maier et al. 1998), a not unexpected finding. In New Zealand, where Se fertilisation has been practised for over 30 years, no Se build-up has occurred, and positive responses continue to be obtained from Se application (Oldfield, 1999). It would appear that the risk of environmental Se accumulation due to responsible agricultural use is low.

Most studies have shown selenate, whether applied to the soil or as a foliar fertiliser, to be much more effective than selenite (Ylaranta 1983a,b, 1984; Singh, 1991; Shand et al. 1992; Gupta et al. 1993). For example, a grain Se content of $100-200 \mu \mathrm{g} / \mathrm{kg}$ in barley was obtained by applying 10-20 g selenate/ha, but over $100 \mathrm{~g}$ selenite/ha was required to reach this level (Ylaranta, 1983b). On a fine sandy loam of $\mathrm{pH} 6 \cdot 0,10 \mathrm{~g}$ selenate/ha applied to the soil raised barley grain from 33 (control) to $234 \mu \mathrm{g} / \mathrm{kg}$, while $10 \mathrm{~g}$ selenite/ha caused no increase (Gupta et al. 1993). In many soils, selenite is readily adsorbed on clay colloids and becomes unavailable to plants.

The relative effectiveness of soil or foliar application of Se depends on Se form, soil characteristics, method of basal application and time of foliar application. Ylaranta (1983b) found basal and foliar selenate to be equally effective at the low $(10 \mathrm{~g} / \mathrm{ha})$ rate, foliar better at $50 \mathrm{~g} / \mathrm{ha}$, and both equal at the high rate of $500 \mathrm{~g} / \mathrm{ha}$. In further trials, foliar selenate applied at the three to four leaf stage was found to be more effective than basal application on clay soil of $\mathrm{pH} 6 \cdot 3$, of similar effectiveness on high-humus, fine sandy soil of $\mathrm{pH}$ $4 \cdot 6$, and slightly less effective than basal fertiliser on a fine sandy soil of $\mathrm{pH} 5 \cdot 0$. Foliar selenate, at the level of $10 \mathrm{~g} / \mathrm{ha}$, using a wetting agent, raised the wheat-grain Se level from 16 to $168 \mu \mathrm{g} / \mathrm{kg}$ on the clay soil, while $9 \mathrm{~g}$ basally applied raised it to just $77 \mu \mathrm{g} / \mathrm{kg}$. Overall, foliar application was the more effective method, except where growth was poor due to low rainfall (Ylaranta, 1984). This suggests that, for most of Australia's wheat-growing areas, basal application may be preferable, especially where foliar N (to which Se could be added) to boost growth or protein is not used.

At the Se levels used for fertilisation of wheat in the field $(5-100 \mathrm{~g} / \mathrm{ha})$, it is unlikely that there would be any phytotoxic effects, including growth inhibition.

The question arises as to what is a desirable target level for Se in wheat grain. From the studies discussed earlier, it is evident that $10 \mathrm{~g}$ selenate/ha can raise wheat crops from a base level of 30-100 to $200-500 \mu \mathrm{g}$ grain-Se $/ \mathrm{kg}$. Is this as high as required? It could be considered a minimum target level in view of the estimated $300 \mu \mathrm{g}$ Se level of a loaf of wholemeal bread made from this wheat. The consumption of this bread over a week would substantially increase an individual's Se intake.

There are no published studies of Se fertilisation of wheat in Australia. Conditions are very different from those in Europe and Canada, where most studies have been conducted; in Australia, rainfall and yield are lower and temperatures higher. Our group is currently conducting field trials to assess different application methods and rates of selenate on wheat in South Australia.

\section{Wheat breeding to increase grain selenium density}

The extent of human micronutrient malnourishment. Around half of the world's population is malnourished. More than two billion individuals consume diets that are less diverse than 30 years ago, leading to deficiencies in micronutrients, especially $\mathrm{Fe}, \mathrm{Zn}, \mathrm{I}$ and $\mathrm{Se}$, and also vitamin A. In some regions, almost everyone suffers from some form of 'hidden hunger'. In South-East Asia, for example, it is estimated that Fe deficiency affects $98.2 \%$ (around 1.4 billion) of the population (World Health Organization, 1999).

Cereals are generally low in micronutrients compared with other food crops, thus cereal-dominated food systems are low in micronutrients. The individuals most at risk are resource-poor women, infants and children. Graham et al. (2001) concluded that a new agricultural paradigm is needed to address global micronutrient malnutrition: ' ... an agriculture which aims not only for productivity and sustainability, but also for balanced nutrition, or what we have called the productive, sustainable, nutritious food systems paradigm.' (Graham et al. 2001, p. 91).

Breeding for higher nutrient density in staple crops. Programmes that include fortification, education and supplementation have been successful in countering micronutrient deficiencies in certain cases and will continue to play a role. However, they tend to be expensive, require ongoing inputs and often fail to reach all individuals at risk. Furthermore, such programmes themselves are at risk from economical, political and logistical impacts (Gibson, 1994; Graham \& Welch, 1996).

On the other hand, a strategy of breeding staple crops with enhanced ability to fortify themselves with micronutrients offers a sustainable, cost-effective alternative, which is more likely to reach those most in need and has the added advantage of requiring no change in current consumer behaviour to be effective. It represents a strategy of 'tailoring the plant to fit the soil' rather than the opposite, which is afforded by the soil fertilisation approach (Graham et al. 2001).

Exploiting the genetic variation in crop plants for micronutrient density is likely to be an effective method to improve the nutrition of entire populations. A four- to fivefold variation was found between the lowest and highest grain $\mathrm{Fe}$ and $\mathrm{Zn}$ concentrations among wheat accessions 
studied at Centro Internacional de Mejoramiento de Maiz y Trigo (International Maize and Wheat Improvement Centre) (CIMMYT), and the highest concentrations were double those of popular modern varieties (Graham et al. 2001). Moreover, wild, small-seeded relatives of modern bread wheats have been found with $50 \%$ more $\mathrm{Fe}$ and $\mathrm{Zn}$ than the highest CIMMYT germ plasm studied (OrtizMonasterio, 1998). If, for example, a wheat variety were identified, which was both high-yielding and produced twice the grain Se density of most other varieties (i.e. 100 instead of $50 \mu \mathrm{g} \mathrm{Se} / \mathrm{kg}$ on a relatively low-Se soil), it could, assuming wheat supplies $50 \%$ of available Se ingested in Australia, result in an increase in Se intake from the current estimate of $75 \mu \mathrm{g} /$ adult per $\mathrm{d}$ to $113 \mu \mathrm{g} /$ adult per $\mathrm{d}$, with significant health benefits.

Graham et al. (2001) emphasised the importance of combining nutrient-density traits with high yield. There is unlikely to be a premium paid for a higher quality product by resource-poor consumers, so new, high-nutrient varieties must also be attractive to farmers in terms of yield. In all the crops examined so far, it is possible to combine high micronutrient density with high yield. These authors also stress the importance of bioavailability; will the added nutrients be sufficient to have a significant effect on human nutrient status? As discussed on p. 52, wheat-Se is highly bioavailable.

A benefit-cost analysis of a breeding approach to increase wheat-grain $\mathrm{Zn}$ density in Turkey, using very conservative assumptions and current dollar values, estimated that costs of US $\$ 13$ million would produce benefits of US \$274 million (economic only, with no account taken of improved health and quality of life), a favourable benefit : cost ratio of 21 (Graham et al. 2001). In contrast, conventional fortification requires yearly funding, and if the investment is not sustained, the benefits cease.

Screening and selection: the importance of genotypeenvironment interaction. In the screening phase of a breeding programme, genotype-environment interaction needs to be relatively low for a breeding approach to be viable. Field trials where different genotypes are grown at the same site in the same season should enable comparison of genotypes. Ideally, trials should be conducted for 2 years at the same site, as different grain nutrient levels of genotypes grown on different soils can even be reflected in the first-year grain harvested. Furthermore, the variability in soil availability for micronutrients is generally much greater than that for macronutrients (Graham, 1991), hence field trials need to be of limited area to reduce spatial variability; paired-plots, where each replicate comprises adjacent treatment and control plots, can be a useful technique.

A major gene together with several minor additive genes are likely to control the uptake of nutrients into crop plants, and another group of genes, also featuring a major gene, appear to control grain loading (Epstein, 1972; Ripperger \& Schreiber, 1982; Graham, 1984). In selecting for grain Se density, both high uptake from the soil and high capacity to move Se from the vegetative tissues to the grain are required. However, as Se is not known to be essential for higher plants, agronomic efficiency may not be involved. Nevertheless, an increase in loading efficiency into the grain is desirable. This could be achieved by the endogenous chelator of $\mathrm{Se}$ in the phloem which increases Se transport to the inflorescence, or by more transporters at the plasma membrane at unloading or uptake into the grain.

Gene technology, including the use of molecular markers (cDNA, restriction fragment length polymorphisms, amplified fragment length polymorphisms and randomly amplified polymorphic DNA) for the mRNA expressed by efficiency and grain-loading genes, provides an alternative to conventional plant breeding as a means to enhance micronutrient density in cereals (Graham et al. 1997). The introduction, for example, of a gene that facilitates expression of the permease sulfate transporter would be likely to increase uptake and transport of selenate.

Surveys of Se level in grains have suggested that environment may be more important than genotype in determining grain Se density. The Queensland study of Noble \& Barry (1982), discussed on p. 51, found differences in Se concentration in wheat of up to 100-fold at different sites, but little difference between wheat varieties. The maximum variation for both species and varieties at any site was five-fold. A Japanese study found that Se levels in rice grown in different parts of the country varied from 11 to $182 \mu \mathrm{g} / \mathrm{kg}$. A significant difference was found between levels in rice from different districts, but not between different rice varieties grown on the same soil (Yoshida \& Yasumoto, 1987). Our group has found up to a six-fold variation in grain Se concentration in one wheat cultivar at a trial site in South Australia.

Genotypic differences were apparent, however, in a study of Se in hulled (spelt and emmer accessions) and modern bread and durum wheats, grown together. The hulled wheats had higher concentrations of $\mathrm{Se}, \mathrm{Li}, \mathrm{Mg}, \mathrm{P}$ and Zn. Five spelt accessions had twice the Se concentrations of emmer, and from two to eight times those of normal wheat (Piergiovanni et al. 1997). This is in contrast to the findings of Grela (1996), who observed no Se differences between spelt and wheat. It is not clear at this stage whether sufficient genetic variability for grain Se density exists between wheat cultivars to enable selection for this trait, and further research is proceeding.

\section{Conclusion}

Research results continue to illustrate the importance of Se in human health, in particular its anti-inflammatory, anticancer and anti-viral activities. It is evident, due mainly to its poor availability in many soils, that as many as one billion individuals may be Se-deficient. The vast majority of the world's population would receive well below the level needed to maximise cancer prevention, which is likely to be within the range of 125-280 $\mu \mathrm{g} / \mathrm{adult}$ per $\mathrm{d}$, depending on gender, pregnancy and exposure to oxidative stress. The average Australian adult would ingest around $75 \mu \mathrm{g} \mathrm{Se} / \mathrm{d}$.

Se levels in Australian wheat are generally moderate, but due to widespread wheat consumption and the high bioavailability of $\mathrm{Se}$ in wheat, this source probably accounts for nearly half the Se utilised by Australians. An increase in the Se content of wheat grain is likely to be the most cost-effective method to increase Se levels in the 
human population. A substantial increase in population Se intake may result in decreased rates of several important cancers, cardiovascular disease, viral disease sequelae, and a range of other conditions that involve oxidative stress and inflammation, with resultant reductions in health costs.

The most promising strategies to increase Se in wheat appear to be biofortification by Se fertilisation and breeding wheat varieties with superior ability to accumulate Se in the grain. Studies in Europe and North America have shown that the addition of as little as $10 \mathrm{~g} \mathrm{Se} / \mathrm{ha}$ can increase grain Se level by up to $0.40 \mathrm{mg} / \mathrm{kg}$. However, studies are needed to determine the most efficient methods for Australian conditions, and to determine the extent of genetic variability for grain Se accumulation.

Furthermore, before recommending large-scale fortification of the food supply with $\mathrm{Se}$, it will be necessary to await the results of current intervention studies with Se on cancer (including the SELECT and PRECISE trials), asthma, and HIV and AIDS.

\section{Acknowledgements}

The generous support provided by the Australian Grains Research and Development Corporation, the Australian Research Council and Waite Analytical Services is gratefully acknowledged. Thank you to Dr Julia Humphries for assistance with the manuscript.

\section{References}

Alfthan G \& Neve J (1996) Selenium intakes and plasma selenium levels in various populations. In Natural Antioxidants and Food Quality in Atherosclerosis and Cancer Prevention, pp. 161-167 [J Kumpulainen and J Salonen, editors]. Cambridge, UK: Royal Society of Chemistry.

Allan CB, Lacourciere GM \& Stadtman TC (1999) Responsiveness of selenoproteins to dietary selenium. Annual Reviews of Nutrition 19, 1-16.

Angstwurm MWA, Schottdorf J, Schopohl J \& Gartner R (1999) Selenium replacement in patients with severe systemic inflammatory response syndrome improves clinical outcome. Critical Care Medicine 27, 1807-1813.

Aro A, Alfthan G \& Varo P (1995) Effects of supplementation of fertilizers on human selenium status in Finland. Analyst 120, 841-843.

Ashour MN, Salem SI, El-Gadban HM, Elwan NM \& Basu TK (1999) Antioxidant status in children with protein-calorie malnutrition (PEM) living in Cairo, Egypt. European Journal of Clinical Nutrition 52, 669-673.

Babidge PJ (1990) Selenium concentrations in South Australian wheat and barley. Proceedings of the Australian Society of Animal Production 18, 452.

Baeten JM, Mostad SB, Hughes MP, Overbaugh J, Bankson DD, Mandaliya K, Ndinya-Achola JO, Bwayo JJ \& Kreiss JK (2001) Selenium deficiency is associated with shedding of HIV1 -infected cells in the female genital tract. Journal of Acquired Immune Deficiency Syndromes 26, 360-364.

Barclay MNI \& MacPherson A (1992) Selenium content of wheat for bread making in Scotland and the relationship between glutathione peroxidase levels in whole blood and bread consumption. British Journal of Nutrition 68, 261-270.
Barclay MNI, MacPherson A \& Dixon J (1995) Selenium content of a range of UK foods. Journal of Food Composition and Analysis 8, 307-318.

Barrett J, Patterson C, Reilly C \& Tinggi U (1989) Selenium in the diet of children with phenylketonuria. In Nutrient Availability: Chemical and Biological Aspects, pp. 281-283 [DAT Southgate, IT Johnson and GR Fenwick, editors]. London, UK: Royal Society of Chemistry.

Barrington JW, Lindsay P, James D, Smith S \& Roberts A (1996) Selenium deficiency and miscarriage: a possible link? British Journal of Obstetrics and Gynaecology 103, 130-132.

Baum MK \& Shor-Posner G (1998) Micronutrient status in relationship to mortality in HIV-1 disease. Nutrition Reviews $\mathbf{5 6}$, S135-S139.

Baum MK, Shor-Posner G \& Lai S (1997) High risk of HIVrelated mortality is associated with selenium deficiency. Journal of Acquired Immune Deficiency Syndromes 15, 370-374.

Beath OA, Eppson HF \& Gilbert CS (1937) Selenium distribution in and seasonal variation of vegetation occurring on seleniferous soil. Journal of the American Pharmaceutical Association 26, 394-398.

Beck MA (2001) Antioxidants and viral infections: host immune response and viral pathogenicity. Journal of the American College of Nutrition 20, Suppl. 5, S384-S388.

Beck MA, Esworthy RS, Ho YS \& Chu FF (1998) Glutathione peroxidase protects mice from viral-induced myocarditis. Federation of American Societies for Experimental Biology Journal 12, 1143-1149.

Beck MA, Shi Q, Morris VC \& Levander OA (1995) Rapid genomic evolution of a non-virulent Coxsackievirus B3 in selenium-deficient mice results in selection of identical virulent isolates. Nature Medicine 1, 433-436.

Beckett GJ, Beddows SE \& Morrice PC (1987) Inhibition of hepatic deiodination of thyroxine is caused by selenium deficiency in rats. Biochemical Journal 248, 443-447.

Behne D, Kyriakopoulos A \& Kalcklosh M (1997) Two new selenoproteins found in the prostatic glandular epithelium and the spermatid nuclei. Biomedical and Environmental Sciences 10, 340-345.

Berrow ML \& Ure AM (1989) Geological materials and soils. In Occurrence and Distribution of Selenium, pp. 226-228 [M Ihnat, editor]. Boca Raton, FL: CRC Press.

Bird SM, Uden PC, Tyson JF, Block E \& Denoyer E (1997) Speciation of selenoamino acids and organoselenium compounds in selenium-enriched yeast using high-performance liquid chromatography-inductively coupled plasma mass spectrometry. Journal of Analytical Atomic Spectrometry 12, 785-788.

Boila RJ, Stothers SC \& Campbell LD (1993) The concentration of selenium in the grain from wheat, barley and oats grown at selected locations throughout Manitoba. Canadian Journal of Animal Science 73, 217-221.

Boyne R \& Arthur J (1986) The response of selenium-deficient mice to Candida albicans infection. Journal of Nutrition $\mathbf{1 1 6}$, 816-822.

Brock K, Gridley G, Morris J \& Willett W (1991) Serum selenium level in relation to in situ cervical cancer in Australia. Journal of the National Cancer Institute 83, 292-293.

Brooks JD, Metter EJ, Chan DW, Sokoll LJ, Landis P, Nelson WG, Muller D, Andres R \& Carter HB (2001) Plasma selenium level before diagnosis and the risk of prostate cancer development. Journal of Urology 166, 2034-2038.

Broyer TC, Lee DC \& Asher CJ (1966) Selenium nutrition of green plants. Effect of selenite supply on growth and selenium content of alfalfa and subterranean clover. Plant Physiology 41, $1425-1428$. 
Bugel S, Sandstrom B, Larsen EH \& Skibsted LH (2002) Is selenium from animal sources bioavailable? 11th Symposium on Trace Elements in Man and Animals, 2-6 June 2002. Berkeley, CA: Trace Elements in Man and Animals Committee.

Burk RF (2002) Selenium, an antioxidant nutrient. Nutritional Clinical Care 5, 75-79.

Campa A, Shor-Posner G \& Indacochea F (1999) Mortality risk in selenium-deficient HIV-positive children. Journal of Acquired Immune Deficiency Syndromes 20, 508-513.

Cary EE \& Allaway WH (1969) The stability of different forms of selenium applied to low-selenium soils. Soil Science Society of America Proceedings 33, 571.

Cary EE \& Gissel-Nielsen G (1973) Effect of fertiliser anions on the solubility of native and applied selenium in soil. Soil Science Society of America Proceedings 37, 590.

Chen X, Mikhael SS, Ding YW, Yang GY, Bondoc F \& Yang CS (2000) Effects of vitamin E and selenium supplementation on esophageal adenocarcinogenesis in a surgical model with rats. Carcinogenesis 21, 1531-1536.

Clark LC, Combs GF, Turnbull BW, Slate EH, Chalker DK, Chow J, Davis LS, Glover RA, Graham GF, Gross EG, Krongrad A, Lesher JL, Park HK, Sanders BB, Smith CL \& Taylor JR (1996) Effects of selenium supplementation for cancer prevention in patients with carcinoma of the skin. Journal of the American Medical Association 276, 1957-1963.

Combs GF (1988) Selenium in foods. In Advances in Food Research, pp. 85-113 [CO Chichester and BS Schweiger, editors]. San Diego, CA: Academic Press.

Combs GF (2000) Considering the mechanisms of cancer prevention by selenium. In Nutrition and Cancer Prevention, pp. 107-117 [AICR Kluwer Academic, editor]. New York, NY: Kluwer Academic/Plenum Publishers.

Combs GF (2001) Selenium in global food systems. British Journal of Nutrition 85, 517-547.

Combs GF \& Gray WP (1998) Chemopreventive agents: selenium. Pharmacology and Therapeutics 79, 179-192.

Cumming F, Fardy JJ \& Woodward DR (1992) Selenium and human lactation in Australia: milk and blood selenium levels in lactating women and selenium intakes of their breast-fed infants. Acta Paediatrica Scandinavica 81, 292-295.

Daniels LA, Gibson RA \& Simmer KN (2000) Indicators of selenium status in Australian infants. Journal of Paediatrics and Child Health 36, 370-374.

Deagen JT, Butler JA, Beilstein MA \& Whanger PD (1987) Effects of dietary selenite, selenocysteine and selenomethionine on selenocysteine lyase and glutathione peroxidase activities and on selenium levels in rat tissue. Journal of Nutrition 117, 91-98.

De las Heras Castano G, Garcia de la Paz A, Fernandez MD \& Fernandez-Forcelledo JL (2000) Use of antioxidants to treat pain in chronic pancreatitis. Revista Espanola de Enfermedades Digestivas 92, 375-385.

Dhindsa HS, Bergmingham MA, Mierzwa J \& Sullivan D (1998) Plasma selenium concentrations in a Sikh population in Sydney, Australia. Analyst 123, 885-887.

Dimitrov N, Meyer C \& Ullrey D (1984) Selenium is a metabolic modulator of phagocytosis. In Selenium in Biology and Medicine, pp. 254-262 [GF Combs, OA Levander, J Spallholz and JE Oldfield, editors]. New York, NY: AVI Publishing.

Diplock A (1994) Antioxidants and disease prevention. Molecular Aspects of Medicine 15, 293-376.

Djujic IS, Jozanov-Stankov ON, Djermanovic V, Demajo M \& Bosni O (2000a) Availability of essential trace elements and their interactions in blood of humans consuming selenium enriched wheat. Selenium 2000, Venice, 1-5 October 2000 (poster). Accessed online 29 November 2001. www.tiresias.bio.unipd.it/HomeSele/postlist.htm
Djujic IS, Jozanov-Stankov ON, Milovac M, Jankovic V \& Djermanovic V (2000b) Bioavailability and possible benefits of wheat intake naturally enriched with selenium and its products. Biological Trace Element Research 77, 273-285.

Duffield-Lillico AJ, Reid ME, Turnbull BW, Combs GF, Slate EH, Fischbach LA, Marshall JR \& Clark LC (2002) Baseline characteristics and the effect of selenium supplementation on cancer incidence in a randomized clinical trial: a summary report of the Nutritional Prevention of Cancer Trial. Cancer Epidemiology, Biomarkers and Prevention 11, 630-639.

Dylewski ML, Mastro AM \& Picciano MF (2002) Maternal selenium nutrition and neonatal immune system development. Biology of the Neonate 82, 122-127.

El-Bayoumy K (1991) The role of selenium in cancer prevention. In Practice of Oncology, 4th ed., pp. 1-15 [VT deVita, S Hellman and SS Rosenberg, editors]. Philadelphia, PA: Lippincott.

Epstein E (1972) Mineral Nutrition of Plants: Principles and Perspectives. New York, NY: Wiley.

Eurola M, Efholm P, Ylinen M, Koivistoinen P \& Varo P (1990) Effects of selenium fertilization on the selenium content of cereal grains, flour, and bread produced in Finland. Cereal Chemistry 67, 334-337.

Eurola M \& Hietaniemi V (editors) (2000) Report of the Selenium Monitoring Programme 1997-1999. Publications of Agricultural Research Centre of Finland, series B24. Jokioinen, Finland: Agricultural Research Centre of Finland.

Fardy JJ, McOrist GD \& Farrar YJ (1989) The determination of selenium status in the Australian diet using neutron activation analysis. Journal of Radioanalysis and Nuclear Chemistry 133, 397-408.

Finley JW (1999) The retention and distribution by healthy young men of stable isotopes of selenium consumed as selenite, selenate or hydroponically-grown broccoli are dependent on the isotopic form. Journal of Nutrition 129, 865-871.

Finley JW \& Davis CD (2001) Selenium from high-selenium broccoli is utilized differently than selenite, selenate and selenomethionine, but is more effective in inhibiting colon carcinogenesis. Biofactors 14, 191-196.

Frost DV (1981) Selenium and vitamin E as antidotes to heavy metal toxicities. In Selenium in Biology and Medicine [JE Spallholz, JL Martin and HE Ganther, editors]. Westport, CT: AVI Publishing.

Frost DV (1987) Why the level of selenium in the food chain appears to be decreasing. In Selenium in Biology and Medicine, part A, pp. 534-547 [GF Combs, OA Levander and JE Spallholz, editors]. New York, NY: AVI Van Nostrand.

Gibson RS (1994) Zinc nutrition and public health in developing countries. Nutrition Research Reviews 7, 151-173.

Giovannucci E (1998) Selenium and the risk of prostate cancer. Lancet 352, 755-756.

Gissel-Nielsen G (1998) Effects of selenium supplementation of field crops. In Environmental Chemistry of Selenium, pp. 99-112 [WT Frankenberger and RA Engberg, editors]. New York, NY: Dekker.

Godwin KO (1975) The role and the metabolism of selenium in the animal. In Trace Elements in Soil-Plant-Animal Systems, pp. 259-270 [DJD Nicholas and AR Egan, editors]. New York, NY: Academic Press.

Golubkina NA \& Alfthan GV (1999) The human selenium status in 27 regions of Russia. Journal of Trace Elements in Medicine and Biology 13, 15-20.

Graham RD (1984) Breeding for nutritional characteristics in cereals. Advances in Plant Nutrition 1, 57-102.

Graham RD (1991) Breeding wheats for tolerance to micronutrient deficient soil: present status and priorities. In Wheat for the Nontraditional Warm Areas [DA Saunders, editor]. Mexico City, Mexico: CIMMYT. 
Graham RD, Senadhira D, Beebe SE, Iglesias C \& OrtizMonasterio I (1999) Breeding for micronutrient density in edible portions of staple food crops: conventional approaches. Field Crops Research 60, 57-80.

Graham RD, Senadhira D \& Ortiz-Monasterio I (1997) A strategy for breeding staple-food crops with high micronutrient density. Soil Science and Plant Nutrition 43, 1153-1157.

Graham RD \& Welch RM (1996) Breeding for staple food crops with high micronutrient density. In Agricultural Strategies for Micronutrients - Working Paper 3. Washington, DC: International Food Policy Research Institute.

Graham RD, Welch RM \& Bouis HE (2001) Addressing micronutrient malnutrition through enhancing the nutritional quality of staple foods: principles, perspectives and knowledge gaps. Advances in Agronomy 70, 77-142.

Grela ER (1996) Nutrient composition and content of antinutritional factors in spelt (T. Spelta L) cultivars. Journal of Science in Food and Agriculture 71, 399-404.

Gupta UC \& Gupta SC (2000) Selenium in soils and crops, its deficiencies in livestock and humans: implications for management. Communications in Soil Science and Plant Analysis 31, 1791-1807.

Gupta UC \& Watkinson JH (1985) Agricultural significance of selenium. Outlook in Agriculture 14, 183-189.

Gupta UC \& Winter KA (1975) Selenium content of soils and crops and the effects of lime and sulfur on plant selenium. Canadian Journal of Soil Science 55, 161-166.

Gupta UC, Winter KA \& Sanderson JB (1993) Selenium content of barley as influenced by selenite- and selenate-enriched fertilizers. Communications in Soil Science and Plant Analysis 24, $1165-1170$.

Hakkarainen J (1993) Bioavailability of selenium. Norwegian Journal of Agricultural Science 11, 21-35.

Harrison P, Lanfear J \& Wu L (1997) Chemopreventive and growth inhibitory effects of selenium. Biomedical and Environmental Sciences 10, 235-245.

Hawkes WC \& Turek PJ (2001) Effects of dietary selenium on sperm motility in healthy men. Journal of Andrology 22, 764-772.

Holden JM, Gebhardt S, Davis CS \& Lurie DG (1991) A nationwide study of the selenium contents and variability in white bread. Journal of Food Composition and Analysis 4, 183-195.

House WA (1999) Trace element bioavailability as exemplified by iron and zinc. Field Crops Research 60, 115-141.

Ip C (1998) Lessons from basic research in selenium and cancer prevention. Journal of Nutrition 128, 1845-1854.

Ip C, Hayes C, Budnick R \& Ganther H (1991) Chemical form of selenium, critical metabolites, and cancer prevention. Cancer Research 51, 595-600.

Ip C \& Lisk D (1994) Characterisation of tissue selenium profiles and anticarcinogenic responses in rats fed natural sources of selenium-rich products. Carcinogenesis 15, 573-576.

Jaakkola K, Tummavuori J, Pirinen A, Kurkela P, Tolonen M \& Arstila AU (1983) Selenium levels in whole blood of Finnish volunteers before and during organic and inorganic selenium supplementation. Scandinavian Journal of Clinical and Laboratory Investigations 43, 473-476.

Jahnova E, Horvathova M, Gazdik F \& Weissova S (2002) Effects of selenium supplementation on expression of adhesion molecules in corticoid-dependent asthmatics. Bratislavske Lekarske Listy 103, 12-16.

Jeong D, Kim TS, Chung YW, Lee BJ \& Kim IY (2002) Selenoprotein $\mathrm{W}$ is a glutathione-dependent antioxidant in vivo. Federation of European Biochemical Societies Letters 517, 225-228.

Jiang C, Jiang W, Ip C, Ganther H \& Lu J (1999) Seleniuminduced inhibition of angiogenesis in mammary cancer at chemopreventive levels of intake. Molecular Carcinogenesis 26, 213-225.

Judson GJ, Mattschoss KH \& Thomas DW (1978) Selenium in whole blood of Adelaide residents. Proceedings of the Nutrition Society of Australia 3, 105.

Judson GJ \& Reuter DJ (1999) Selenium. In Soil Analysis: An Interpretation Manual, pp. 325-329 [KI Peverill, LA Sparrow and DJ Reuter, editors]. Melbourne, Australia: CSIRO Publishing.

Judson GJ, Thomas DW \& Mattschoss KH (1982) Blood selenium levels of Kangaroo Island residents. Medical Journal of Australia 2, 217.

Kauf E, Dawczynski H, Jahreis G, Janitsky E \& Winnefeld K (1994) Sodium selenite therapy and thyroid-hormone status in cystic fibrosis and congenital hypothyroidism. Biological Trace Element Research 40, 247-253.

Kiremidjian-Schumacher L, Roy M, Wishe HI, Cohen MW \& Stotzky G (1994) Supplementation with selenium and human immune cell functions. Biological Trace Element Research 41, $115-127$.

Kohrle J (1999) The trace element selenium and the thyroid gland. Biochimie 81, 527-533.

Korotkov KV, Novoselov SV, Hatfield DL \& Gladyshev VN (2002) Mammalian selenoprotein in which selenocysteine (Sec) incorporation is supported by a new form of Sec insertion sequence element. Molecular Cell Biology 22, 1402-1411.

Kowluru RA, Tang J \& Kern TS (2001) Abnormalities of retinal metabolism in diabetes and experimental galactosemia. 7. Effect of long-term administration of antioxidants on the development of retinopathy. Diabetes 50, 1938-1942.

Kurihara M, Kumagai K, Nakae Y, Nishino I \& Nonaka I (2000) Two sibling patients with non-Fukuyama type congenital muscular dystrophy with low serum selenium levels - therapeutic effects of oral selenium supplementation. No To Hattatsu 32, 346-351.

Kurz B, Jost B \& Schunke M (2002) Dietary vitamins and selenium diminish the development of mechanically induced osteoarthritis and increase the expression of antioxidative enzymes in the knee joint of STR/1N mice. OsteoarthritisCartilage 10, 119-126.

Lag J \& Steinnes E (1978) Regional distribution of selenium and arsenic in humus layers of Norwegian forest soils. Geoderma 20, 3-14.

Laws JE, Latshan JD \& Biggert M (1986) Relative biological values of selenium. Feed experiment with chickens. Nutrition Reports International 33, 13-24.

Levander OA \& Beck MA (1999) Selenium and viral virulence. British Medical Bulletin 55, 528-533.

Levander OA \& Burk RF (1990) Selenium. In Present Knowledge of Nutrition, 6th ed., pp. 268-273 [ML Brown, editor]. Washington, DC: Nutrition Foundation.

Lindstrom K (1983) Selenium as a growth factor for plankton algae in laboratory experiments and in some Swedish lakes. Hydrobiologia 101, 35-48.

Liu BS \& Li SS (1987) Primary study of relationship between endemic selenosis and fluorosis. In Selenium in Biology and Medicine, vol. B, pp. 708-711 [GF Combs, JE Spallholz, OA Levander and JE Oldfield, editors]. Westport, CT: AVI Publishing.

Liu Y, Chiba M, Inaba Y \& Kondo M (2002) Keshan disease: a review from the aspect of history and etiology. Japanese Journal of Hygiene 56, 641-648.

Look MP, Rockstroh JK, Rao GS, Kreuzer KA, Spengler U \& Sauerbruch T (1997) Serum selenium versus lymphocyte subsets and markers of disease progression and inflammatory response in human immunodeficiency virus-infection. Biological Trace Element Research 56, 31-41. 
Lu J (2000) Apoptosis and angiogenesis in cancer prevention by selenium. In Nutrition and Cancer Prevention, pp. 131-145 [AICR Kluwer Academic, editor]. New York, NY: Plenum Publishers.

Lux O \& Naidoo D (1995) The assessment of biological variation components of copper, zinc and selenium. Journal of Nutritional Biochemistry 6, 43-47.

McGlashan ND, Cook SJ, Melrose W, Martin PL, Chelkowska E \& von Witt RJ (1996) Maternal selenium levels and sudden infant death syndrome (SIDS). Australian and New Zealand Journal of Medicine 26, 677-682.

McOrist \& Fardy JJ (1989) Selenium status in the blood using neutron activation analysis. Journal of Radioanalytical and Nuclear Chemistry 134, 65-72.

Maier KJ, Nelson CR, Bailey FC, Klaine SJ \& Knight AW (1998) Accumulation of selenium by the aquatic biota of a watershed treated with seleniferous fertilizer. Bulletin of Environmental Contamination and Toxicology 60, 409-416.

Meltzer HM, Norheim G, Loken EB \& Holm H (1992) Supplementation with wheat selenium induces a dose-dependent response in serum and urine of a selenium-replete population. British Journal of Nutrition 67, 287-294.

Mihailovic M, Lindberg P \& Jovanovic I (1996) Selenium content in feedstuffs in Serbia. Acta Veterinaria Beograd 46, 343-348.

Ministry of Agriculture, Fisheries and Food (1997) Dietary Intake of Selenium. Food Surveillance Information Sheet no. 126. London, UK: Joint Food Safety and Standards Group.

Ministry of Agriculture, Fisheries and Food (1999) Total Diet Study - Aluminium, Arsenic, Cadmium, Chromium, Copper, Lead, Mercury, Nickel, Selenium, Tin and Zinc. Food Surveillance Information Sheet no. 191. London, UK: Joint Food Safety and Standards Group.

Moser-Veillon PB, Mangeb AR, Patterson KY \& Veillon C (1992) Utilization of two different chemical forms of Se during lactation using stable isotope tracers: an example of speciation in nutrition. Analyst 117, 559-562.

Moyad MA (2002) Selenium and vitamin E supplements for prostate cancer: evidence or embellishment? Urology 59, Suppl. 4A, 9-19.

Mutanen M, Koivistoinen P, Morris VC \& Levander OA (1987) Relative nutritional availability to rats of selenium in Finnish spring wheat (Triticum aestivum L.) fertilized or sprayed with sodium selenate and in an American winter bread wheat naturally high in Se. British Journal of Nutrition 57, 319-329.

Neve J (1991) Physiological and nutritional importance of selenium. Experientia 47, 187-193.

Neve J (1995) Human selenium supplementation as assessed by changes in blood selenium concentration and glutathione peroxidase activity. Journal of Trace Elements in Medicine and Biology 9, 65-73.

Neve J (1996) Selenium as a risk factor for cardiovascular diseases. Journal of Cardiovascular Risk 3, 42-47.

Neve J (1999) Combined selenium and iodine deficiency in Kashin-Beck osteoarthropathy. In STDA Bulletin, pp. 1-3. Grimbergen, Belgium: Selenium-Tellurium Development Association.

Neve J (2000) New indices for assessment of trace element status and requirement with a special focus on selenium. In Trace Elements in Man and Animals 10: Proceedings of the Tenth International Symposium on Trace Elements in Man and Animals, pp. 317-322 [AM Roussel, A Favier and RA Anderson, editors]. New York: Plenum Press.

Noble RM \& Barry GA (1982) Survey of selenium concentrations in wheat, sorghum and soybean grains, prepared poultry feeds and feed ingredients from Queensland. Queensland Journal of Agriculture and Animal Science 39, 1-8.
Norman BB, Nader G \& Oliver M (1992) Effects of selenium supplementation in cattle on aquatic ecosystems in California. Journal of the American Veterinary Medicine Association 201, 869-872.

Oldfield JE (1993) Selenium in fertilizers. In STDA Bulletin (Special issue), pp·1-4. Grimbergen, Belgium: SeleniumTellurium Development Association.

Oldfield JE (1999) The case for selenium fertilization: an update. In STDA Bulletin, August. Grimbergen, Belgium: SeleniumTellurium Development Association.

Olson OE, Novacek EJ, Whitehead EI \& Palmer IC (1970) Investigations on selenium in wheat. Phytochemistry 9, $1181-1188$.

Ortiz-Monasterio I (1998) CGIAR Micronutrients Project, Update no. 3,5. Washington, DC: International Food Policy Research Institute.

Pearn J \& McCay CRW (1979) Blood selenium in chronic spinal muscular atrophy. Journal of Neurological Science 42, 199-202.

Peng A, Wang WH, Wang CX, Wang ZJ, Rui HF, Wang WZ \& Yang ZW (1999) The role of humic substances in drinking water in Kaschin-Beck disease in China. Environmental Health Perspectives 107, 293-296.

Peretz A, Siderova V \& Neve J (2001) Selenium supplementation in rheumatoid arthritis investigated in a double blind, placebocontrolled trial. Scandinavian Journal of Rheumatology 30, 208-212.

Piergiovanni AR, Rizzi R, Pannacciulli E \& Della Gatta C (1997) Mineral composition in hulled wheat grains: a comparison between emmer (Triticum dicoccon Schrank) and spelt ( $T$. Spelta L) accessions. International Journal of Food Sciences and Nutrition 48, 381-386.

Poirier KA (1994) Summary of the derivation of the reference dose for selenium. In Risk Assessment of Essential Elements, pp. 157-166 [W Mertz, CO Abernathy and SS Olin, editors]. Washington, DC: ILSI Press.

Raghib MH, Chan WY \& Rennert OM (1986) Comparative studies of selenium-75 (selenite and selenomethionine) absorption from various milk diets in suckling rats. Journal of Nutrition 116, 1456-1463.

Rayman MP (1997) Dietary selenium: time to act. British Medical Journal 314, 387-388.

Rayman MP (2000) The importance of selenium to human health. Lancet 356, 233-241.

Rayman MP (2002) The argument for increasing selenium intake. Proceedings of the Nutrition Society 61, 203-215.

Rayman MP \& Clark LC (2000) Selenium in cancer prevention. In Trace Elements in Man and Animals - 10: Proceedings of the Tenth International Symposium on Trace Elements in Man and Animals, pp. 575-580 [AM Roussel, A Favier and RA Anderson, editors]. New York, NY: Plenum Press.

Reilly C (1996) Selenium in Food and Health. London, UK: Blackie.

Reuter DJ (1975) Selenium in soils and plants: a review in relation to selenium deficiency in South Australia. Agricultural Record 2, July issue.

Ripperger H \& Schreiber K (1982) Nicotianamine and analogous amino acids, endogenous iron carriers in higher plants. Heterocycles 17, 447-461.

Robberecht HJ \& Deelstra HA (1994) Factors influencing blood selenium concentrations: a literature review. Journal of Trace Elements and Electrolytes in Health and Disease 8, 129-143.

Schrauzer GN (1998) Selenium: present and future applications in medicine. In STDA Sixth International Symposium, 10-12 May 1998, Scottsdale, USA. Grimbergen, Belgium: SeleniumTellurium Development Association. 
Schrauzer GN (2000) Selenomethionine: a review of its nutritional significance, metabolism and toxicity. Journal of Nutrition 130, 1653-1656.

Schubert A, Holden JM \& Wolfe WR (1987) Selenium content of a core group of foods based on a critical evaluation of published analytical data. Journal of the American Dietetics Association 87, 285-299.

Schwarz K \& Foltz CM (1957) Selenium as an integral part of factor 3 against dietary necrotic liver degeneration. Journal of the American Chemical Society 79, 3292-3293.

Scott R \& MacPherson A (1998) Selenium supplementation in sub-fertile human males. British Journal of Urology 82, 76-80.

Seo YR, Kelley MR \& Smith ML (2002) Selenomethionine regulation of $\mathrm{p} 53$ by a ref1-dependent redox mechanism. Proceedings of the National Academy of Sciences USA 99, 14548-14553.

Shaheen SO, Sterne JAC \& Thompson RL (1999) Dietary antioxidants and asthma in adults. European Respiratory Journal 14, Suppl. 30, 141S.

Shand C, Coutts G, Duff E \& Atkinson D (1992) Soil selenium treatments to ameliorate selenium deficiency in herbage. Journal of Science and Food in Agriculture 59, 27-35.

Shor-Posner G, Miguez MJ, Pineda LM, Rodriguez A, Ruiz P, Castillo G, Burbano X, Lecusay R \& Baum M (2002) Impact of selenium status on the pathogenesis of mycobacterial disease in HIV-1-infected drug users during the era of highly active antiretroviral therapy. Journal of Acquired Immune Deficiency Syndromes 29, 169-173.

Singh BR (1991) Selenium content of wheat as affected by selenate and selenite contained in a Cl- or $\mathrm{SO}_{4}$ based NPK fertilizer. Fertilizer Research 30, 1-7.

Spallholz JE, Boylan LM \& Larsen HS (1990) Advances in understanding selenium's role in the immune system. Annals of the New York Academy of Sciences 587, 123-139.

Stewart RDH, Griffiths NM, Thomson CD \& Robinson MF (1987) Quantitative selenium metabolism in normal New Zealand women. British Journal of Nutrition 40, 45-54.

Taylor EW (1997) Selenium and viral diseases: facts and hypotheses. Journal of Orthomolecular Medicine 12, 227-239.

Taylor EW \& Nadimpalli RG (1999) Chemoprotective mechanisms of selenium in cancer and AIDS: evidence for the involvement of novel selenoprotein genes. Info Onkologi 2, $7-11$.

Terry N, Zayed AM, de Souza MP \& Tarun AS (2000) Selenium in higher plants. Annual Reviews of Plant Physiology and Plant Molecular Biology 51, 401-432.

Thomson CD \& Robinson MF (1980) Selenium in human health and disease with emphasis on those aspects peculiar to New Zealand. American Journal of Clinical Nutrition 33, 303-323.

Thorn J, Robertson J \& Buss DH (1976) Trace nutrients: selenium in British foods. British Journal of Nutrition 39, 391-396.

Tinggi U \& Reilly C (2000) Concentrations of selenium and other major elements (barium, calcium, magnesium, potassium and phosphorus) in Brazil nuts in Brisbane, Queensland. Selenium 2000, Venice, 1-5 October 2000 (poster). Accessed online 29 November 2001. www.tiresias.bio.unipd.it/HomeSele/postlist.htm

Underwood EJ (1977) Trace Elements in Human and Animal Nutrition, 4th ed., pp. 303-345. New York, NY: Academic Press.

University of California (1988) Selenium, human health and irrigated agriculture. In Resources at Risk in the San Joaquin Valley. Davis, CA: University of California Agricultural Issues Center.

Van Campen DR \& Glahn RP (1999) Micronutrient bioavailability techniques: accuracy, problems and limitations. Field Crops Research 60, 93-113.

Van Dael P, Davidsson L, Ziegler EE, Fay LB \& Barclay D (2002)
Comparison of selenite and selenate apparent absorption and retention in infants using stable isotope methodology. Pediatric Research 51, 71-75.

Vanderpas JB, Contempre B, Duale N, Goosens W, Bebe N, Thorpe R, Ntambue K, Dumont J, Thilly CH \& Diplock AT (1993). Iodine and selenium deficiency associated with cretinism in northern Zaire. American Journal of Clinical Nutrition 57, 271S-275S.

Varo P, Alfthan G, Huttunen J \& Aro A (1994) Nationwide selenium supplementation in Finland - effects on diet, blood and tissue levels, and health. In Selenium in Biology and Human Health, pp. 197-218 [R Burk, editor]. New York, NY: Springer-Verlag.

Vinceti M, Wei ET, Malagoli C, Bergomi M \& Vivoli G (2001) Adverse health effects of selenium in humans. Reviews on Environmental Health 16, 233-251.

Vuori E, Vaariskoski J \& Hartikainen H (1994) A long-term study of selenate sorption in Finnish cultivated soils. Agriculture, Ecosystems and Environment 48, 91-98.

Watkinson JH (1981) Changes of blood selenium in New Zealand adults with time and importation of Australian wheat. American Journal of Clinical Nutrition 34, 936-942.

Wei A (1996) Soybean sprout. Zhengzhou Liangshi Xueyuan Xuebao 17, 67-70.

Welch RM \& Graham RD (1999) A new paradigm for world agriculture: meeting human needs. Productive, sustainable, nutritious. Field Crops Research 60, 1-10.

Whanger PD (1992) Selenium in the treatment of heavy metal poisoning and chemical carcinogenesis. Journal of Trace Elements and Electrolytes in Health and Disease 6, 209-221.

Whanger PD (2001) Selenium and the brain: a review. Nutritional Neuroscience 4, 81-97.

Whanger PD, Vendeland S, Park Y-C \& Xia Y (1996) Metabolism of sub-toxic levels of selenium in animals and humans. Annals of Clinical Laboratory Science 26, 99-113.

Whelan BR \& Barrow NJ (1994) Slow-release selenium fertilizers to correct selenium deficiency in grazing sheep in Western Australia. Fertilizer Research 38, 183-188.

White CL, Robson AD \& Fisher HM (1981) Variation in nitrogen, sulphur, selenium, cobalt, manganese, copper and zinc contents of grain from wheat and two lupin species grown in a range of Mediterranean environment. Australian Journal of Agricultural Research 32, 47-59.

World Health Organization (1999) Malnutrition Worldwide. Accessed online 15 June 2000. www.who.int/nut/malnutritionworldwide.htm Geneva, Switzerland: World Health Organization.

Xiong Y, Mo D, Bi H, Li S, Guo X, Yu Z, Luo Y, Feng J, Zhang L \& Yang J (1998) Effect of selenium on lesion of articular cartilage fed on T-2 toxin in Chinese mini-pigs with experimental Kaschin-Beck disease. Xi' an Yike Daxue Xuebao 19, 523-525.

Yang FY, Lin ZH, Xing JR, Li SG, Yang J, San S \& Wu L (1994) Selenium deficiency is a necessary but not sufficient factor required for the pathogenesis of Keshan disease. Journal of Clinical Biochemistry and Nutrition 16, 101-110.

Yang GQ \& Zhou RH (1994) Further studies on human maximum safe dietary selenium intake and a discussion on some related problems. Journal of Trace Elements and Electrolytes in Health and Disease 8, 159-165.

Ylaranta T (1983a) Effect of added selenite and selenate on the selenium content of Italian rye grass (Lolium multiflorum) in different soils. Annales Agriculturae Fenniae 22, 139-151.

Ylaranta T (1983b) Effect of applied selenite and selenate on the selenium content of barley (Hordeum vulgare). Annales Agriculturae Fenniae 22, 164-174.

Ylaranta T (1984) Raising the selenium content of spring wheat and barley using selenite and selenate. Annales Agriculturae Fenniae 23, 75-84. 
Yoshida M \& Yasumoto K (1987) Selenium contents of rice grown at various sites in Japan. Journal of Food Composition and Analysis 1, 71-75.

Yoshizawa K, Willett WC, Morris SJ, Stampfer MJ, Spiegelman D, Rimm EB \& Giovannucci E (1998) Study of prediagnostic selenium level in toenails and the risk of advanced prostate cancer. Journal of the National Cancer Institute 90, 1219-1224.

Yu MW, Horng IS, Chiang YC, Liaw YF \& Chen CJ (1999) Plasma selenium levels and the risk of hepatocellular carcinoma among men with chronic hepatitis virus infection. American Journal of Epidemiology 150, 367-374.
Yu SY, Zhu YJ \& Li WG (1997) Protective role of selenium against hepatitis b virus and primary liver cancer in Qidong. Biological Trace Element Research 56, 117-124.

Zhang F, Yu W, Hargrove JL, Greenspan P, Dean RG, Taylor EW \& Hartle DK (2002) Inhibition of TNF-alpha induced ICAM-1, VCAM-1 and E-selectin expression by selenium. Atherosclerosis 161, 381-386.

Zhao L, Cox AG, Ruzicka JA, Bhat AA, Zang W \& Taylor EW (2000) Molecular modelling and in vitro activity of an HIV-1 encoded glutathione peroxidase. Proceedings of the National Academy of Sciences USA 97, 6356-6361. 